
ISSN : 2615-1995, E-ISSN : 2615-0654

J. Madani., Vol. 1, No. 1, Maret 2018 (235-352)

(C)2018 Lembaga Kajian Demokrasi

MADAN

dan Pemberdayaan Masyarakat (LKD-PM)

\title{
PENGARUH MOTIVASI TERHADAP PRODUKTIVITAS KERJA KARYAWAN PADA PT USAHA TEKNIK INDONESIA
}

\author{
Reni Hindriari \\ Dosen Fakultas Ekonomi, Universitas Pamulang \\ reni.hindriari@gmail.com
}

\begin{abstract}
ABSTRAK
Penelitian ini bertujuan untuk mengetahui Pengaruh Motivasi (Variabel X) Terhadap Produktivitas Kerja Karyawan (Variabel Y) Pada PT Usaha Teknik Indonesia. Metode Penelitian yang digunakan dalam pengumpulan data adalah metode pengumpulan data primer yang meliputi data kuantitatif dan kualitatif dengan teknik observasi, teknik wawancara, dan teknik kuesioner yang dilakukan kepada karyawan PT Usaha Teknik Indonesia sejumlah 61 responden. Berdasarkan hasil penelitian menunjukan adanya hubungan yang signifikan antara Motivasi pada Produktifitas kerja karyawan dengan tingkat hubungan kuat. Hasil penelitian menunjukan koefisien korelasi sebesar rxy $=0,737$, koefisien determinasi sebesar $\mathrm{r}^{2} \mathrm{xy}=54,31$ yang menunjukan bahwa 55\% produktivitas kerja karyawan dipengaruhi oleh motivasi dan 45\% dipengaruhi oleh faktor - faktor lain yang diteliti, uji signifikan t hitung $>\mathrm{t}$ table yaitu 8,3756 $>1,6577$ yang artinya terdapat pengaruh yang signifikan antara motivasi dengan produktivitas kerja karyawan dan uji hipotesis diperoleh 11,0386 > 1,6577 yang artinya hipotesa alternative $(\mathrm{Ha})$ diterima.
\end{abstract}

Kata Kunci : Motivasi, Produktivitas Kerja

\section{PENDAHULUAN}

\section{Latar Belakang Masalah}

Dalam kehidupan masyarakat yang selalu berkembang seiring dengan teknologi daya manusia dalam hal ini tenaga kerja merupakan salah satu faktor produksi yang sangat menentukan berhasil tidaknya suatu perusahaan ataupun organisasi dalam mencapai tujuannya. Setiap perusahaan tentu saja menginginkan agar usahanya mencapai tingkat produktivitas yang tinggi. Oleh karena itu perusahaan harus memperhatikan kesejahteraan karyawannya dan diusahakan agar manajemen perusahaan didu- kung dengan kemampuan dan pengetahuan yang baik dan kuat oleh individu didalamnya.

Manajemen di dalam suatu perusahaan biasanya menghadapi lebih banyak masalah penting bila dibandingkan dengan masalah-masalah bahan baku, mesin serta peralatan lainnya. Pada umumnya masalah pada bidang sumber daya manusia, karena manusia bukanlah benda mati seperti mesin dan peralatan lainnya.

Dalam hal sumber daya manusia ini diperlukan pendekatan yang bersifat manusiawi agar manusia yang bekerja merasa diperlukan seperti manusia yang sutuhnya. Keberhasilan suatu 
perusahaan tidak hanya ditentukan oleh perangkat alat atau fasilitas kerja yang lengkap, tetapi juga ditentukan oleh kualitas tenaga kerjanya. Disamping harus memiliki jumlah tenaga kerja yang mencukupi, perusahaan pun harus membekali karyawannya dengan kemampuan dan keterampilan serta memberikan motivasi yang tinggi.

Pemberian motivasi oleh perusahaan salah satu alternatif untuk dapat meningkatkan produktivitas kerja dari karyawannya, sehingga tujuan perusahaan dapat tercapai. Motivasi itu sendiri merupakan aspek untuk membuat semua orang bergerak, bersemangat atas dasar kemampuan, dedikasi dan loyalitas yang dimiliki pribadinya atau pemberian perangsang berupa imbalan sebagai hasil usahanya.

Seorang pakar manajemen Sondang P. Siagian (2002:56) dalam bukunya filsafat administrasi mengemukakan fungsi - fungsi manajemen salah satunya adalah fungsi "pemberian motivasi”. Fungsi tersebut erat hubungannya dengan unsur manusia, karena secara umum motivasi adalah usaha untuk menyatukan tujuan organisasi dengan tujuan pribadi dari anggota organisasi. Adapun secara tegas motivasi mempunyai pengertian, bahwa para pelaksana yang bekerja dalam memberikan jasa - jasanya memerlukan motivasi.

Sedangkan pemberian motivasi oleh pimpinan dapat memberikan inspirasi, semangat dan dorongan yang dapat meningkatkan produktivitas sumberdaya manusia bawahannya. Sedangkan yang dilakukan oleh PT Usaha Teknik Indonesia sendiri kurang optimalnya semangat kerja sehingga produktivitas kerja karyawan cenderung menurun.

Selain dengan adanya motivasi diharapkan dapat mendorong kegairahan dalam bekerja sehingga mereka bekerja bukan atas dasar paksaan melainkan tugas sebagai rasa tanggung jawab dan kesadaran diri sendiri, sehingga produktivitas kerja karyawan pun dapat meningkat.

Salah satu perusahaan yang berupaya me- ningkatkan produktivitas kerja karyawannya melalui pemberian motivasi adalah PT Usaha Teknik Indonesia. Pemberian motivasi tersebut diberikan kepada karyawan termasuk karyawan bagian produksi dengan latar belakang ingin mengetahui bagaimana pengaruh motivasi kerja terhadap produktivitas kerja pada PT Usaha Teknik Indonesia. Penulis mencoba menuangkan dalam bentuk penelitian dengan judul: "Pengaruh Motivasi Terhadap Produktivitas Kerja Karyawan Pada PT Usaha Teknik Indonesia".

\section{Identifikasi Masalah}

Dalam latar belakang diatas maka diuraikan permasalahan - permasalahan tersebut dan dapat diidentifikasikan sebagai berikut :

1. Motivasi yang di terapkan di PT Usaha Teknik Indonesia belum optimal.

2. Karyawan masih sering mengabaikan peraturan manajemen akibat kurangnya motivasi.

3. Adanya penurunan produktivitas kerja karyawan.

\section{Pembatasan Masalah}

Faktor motivasi kerja yang diteliti adalah faktor - factor motivasi kerja Maslow yang meliputi Physiological needs, Safety needs, Social needs, Esteem needs dan Actualization needs. Penelitian hanya dilakukan pada karyawan PT Usaha Teknik Indonesia mulai 1 Agustus 2016 sampai 30 Oktober 2016.

\section{Perumusan Masalah}

Berdasarkan latar belakang masalah, identifikasi masalah dan pembatasan, maka penulis merumuskan masalah sebagai berikut :

1. Bagaimana motivasi karyawan pada PT Usaha Teknik Indonesia?

2. Bagaimana produktivitas karyawan pada PT Usaha Teknik Indonesia?

3. Seberapa besar pengaruh motivasi terhadap produktivitas kerja karyawan PT Usaha Teknik Indonesia? 


\section{Tujuan dan Manfaat Penelitian}

1. Tujuan penelitian ini adalah :

a. Untuk mengetahui motivasi pada PT Usaha Teknik Indonesia.

b. Untuk mengetahui produktivitas kerja karyawan PT Usaha Teknik Indonesia.

c. Untuk mengetahui seberapa besar motivasi terhadap produktivitas kerja karyawan PT Usaha Teknik Indonesia.

2. Manfaat penelitian

Manfaat penelitian yang dilakukan diharapkan dapat memberikan manfaat yang berguna, baik secara teoritis maupun praktis yaitu :

a. Teoritis

1) Bagi penulis

Manfaat bagi penulis untuk mendalami ilmu manajemen khususnya Manajemen Sumber Daya Manusia dalam aplikasi sesungguhnya.

2) Bagi Akademik

Manfaat bagi Universitas Pamulang yaitu sebagai masukan yang bermanfaat bagi mahasiswa dalam memahami pengetahuan dan diharapkan dapat menambah kelengkapan hasil penelitian dengan masalah yang sama.

3) Praktis

Bagi Perusahaan

Bagi PT Usaha Teknik Indonesia menjadi bahan dalam rangka peningkatan motivasi pegawai, serta menjadi bahan pertimbangan pengambilan keputusan dalam rangka meningkatkan produktifitas karyawan.

\section{Kerangka Berpikir}

Sugiyono (2011 : 60) mengemukakan bahwa "Kerangka berpikir merupakan model konseptual tentang bagaimana teori berhubungan dengan berbagai faktor yang telah diidentifikasi sebagai hal yang penting jadi dengan demikian maka kerangka berpikir adalah sebuah pemahaman yang melandasi pemahaman-pemaha- man yang lainnya, sebuah pemahaman yang paling mendasar dan menjadi pondasi bagi setiap pemikiran atau suatu bentuk proses dari keseluruhan dari penelitian yang akan dilakukan."

Secara spesifik, dapat penulis kemukakan kerangka pemikiran antara motivasi terhadap produktifitas kerja karyawan sebagai berikut :

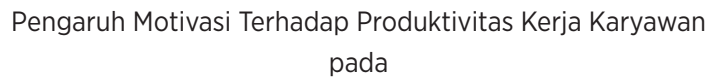

Variabel X (Independen) :

Motivasi

- Kemauan/Keinginan

- Semangat

- Tujuan

- Keyakinan

Hasibuan (2002:102)

Variabel Y (Dependen) :

Produktivitas Karyawan

- $\quad$ Sikap dan Etika

- Disiplin

- Loyalitas

- Inovasi

Mangkunegara (2005:9)

\section{Tinjauan Pustaka \\ Motivasi}

Bagi manajemen motivasi adalah suatu dorongan kehendak yang menyebabkan seseorang melakukan suatu perbuatan untuk mencapai tujuan tertentu. Motivasi berasal dari kata motif yang berarti "dorongan" atau rangsangan atau "daya penggerak" yang ada dalam diri seseorang.

Menurut Siagian (2004:138), memberikan definisi motivasi sebagai daya dorong yang mengakibatkan seseorang mau dan rela untuk mengerahkan kemampuan, tenaga dan waktunya dalam rangka pencapaian tujuan yang telah ditentukan sebelumnya.

Motivasi bukan hanya satu - satunya faktor yang mempengaruhi tingkat prestasi seseorang. Dua faktor lainnya yang terlibat adalah kemampuan individu dan pemahaman tentang perilaku yang diperlukan untuk mencapai prestasi yang tinggi atau disebut persepsi peranan. Motivasi kemampuan dan persepsi peranan adalah saling berhubungan. Jadi, bila salah satu faktor rendah maka tingkat prestasi akan rendah, walaupun faktor - faktor lainnya tinggi. 
Prinsip itu tidak menutupi kondisi bahwa dalam keadaan terpaksa seseorang mungkin saja melakukan sesuatu yang tidak disukai berupa kegiatan yang terpaksa dilakukan, cenderung berlangsung tidak efektif dan efisien. Dengan demikian berarti juga yang menjadi prinsip utama dari segi psikologi.

Menurut A.H Maslow dalam Hasibuan (2002:152-155), kebutuhan dan kepuasan seseorang itu jamak yang dapat dibagi dalam 2 kebutuhan, yaitu kebutuhan biologis dan psikologi berupa materil dan non materil. Selanjutnya Maslow mengatakan :

1. Teori kebutuhan :

a. Manusia adalah makhluk social yang berkeinginan, ia selalu menginginkan lebih banyak. Keinginan ini terus menerus, baru berhenti jika akhir hayat tiba.

b. Suatu kebutuhan yang telah dipuaskan tidak akan menjadi alat motivasi bagi pelakunya, hanya kebutuhan yang belum terpenuhi menjadi alat motivasi.

c. Kebutuhan manusia itu bertingkattingkat (hierarchy) sebagai berikut.

1) Psysiological Needs

Psysiological Needs (kebutuhan fisik = biologis) yaitu kebutuhan yang diperlukan untuk mempertahankan kelangsungan hidup seseorang. Keinginan untuk memenuhi kebutuhan fisik ini merangsang seseorang berperilaku dan bekerja giat. Kebutuhan fisik ini merupakan kebutuhan utama, merupakan tingkat kebutuhan yang bobotnya rendah.

2) Safety and Security Need Safety and Security Need (Keamanan dan Keselamatan) adalah kebutuhan akan keamanan yakni merasa aman dari ancaman kecelakaan dan keselamatan dalam melakukan pekerjaan. Kebutuhan ini mengarah pada dua bentuk antara lain : (a) Kebutuhan akan aman dan kecelakaan jiwa ditempat pekerjaan pada saat mengerjakan pekerjaan di waktu jam-jam kerja.

(b) Kebutuhan akan keamanan harta ditempat pekerjaan pada waktu jamjam kelas. Pentingnya memuaskan kebutuhan ini jelas pada organisasi modern, tempat pimpinan organisasi menggunakan alat-alat canggih atau pengawalan. Bentuk lain dari pemuasan kebutuhan ini dengan memberikan perlindungan asuransi kepada karyawan.

3) Affiliation or Acceptance Need Affiliation or Acceptance Need adalah kebutuhan sosial,kawan dicintai dan mencintai serta diterima dalam pergaulan kelompok karyawan dan lingkungan. Manusia pada dasarnya selalu ingin hidup berkelompok dan tidak seorang pun manusia ingin hidup menyendiri ditempat terpencil.

4) Esteem or Status Need Esteem or Status Need adalah kebutuhan karyawan akan penghargaan diri, pengakuan serta penghargaan prestise dari karyawan dan masyarakat lingkungannya. Idealnya prestasi timbul karena adanya prestasi. Akan tetapi perlu diperhatikan oleh pimpinan bahwa semakin tinggi kedudukan seseorang dalam masyarakat atau posisi seseorang dalam suatu perusahaan maka semakin tinggi pula prestasinya.

5) Self Actualization

Self Actualization adalah kebutuhan akan aktualisasi diri dengan menggunakan kecakapan, kemampuan, keterampilan, dan potensi optimal untuk mencapai prestasi kerja yang sangat memuaskan atau luar biasa yang sulit dicapai orang lain. 
2. Teori Kepuasan

Penganut-penganut teori motivasi kepuasan sebagai berikut : (Malayu Hasibuan, 2003:152)

a) Menurut Frederik Winslow Taylor dengan Teori Motivasi Klasik Freederik Winslow Taylor mengemukakan teori motivasi klasik atau teori kebutuhan tunggal. Teori ini berpendapat bahwa manusia mau bekerja giat untuk memenuhi kebutuhan fisik atau biologisnya, berbentuk uang atau barang dari hasil bekerjanya.

Konsep dasar teori ini adalah orang akan bekerja giat, bila mana ia mendapat imbalan materi yang mempunyai kaitan dengan tugas-tugasnya. Manajer menentukan bagaimana tugas dikerjakan dengan menggunakan sistem insentif untuk memotivasi pekerja. Semakin banyak mereka berproduksi, semakin besar penghasilan mereka.

Direktur atau pegawai mengetahui bahwa kemampuan pegawai atau tidak sepenuhnya dikerahkan untuk melaksanakan pekerjaannya. Pegawai tidak hanya bisa di motivasi dengan memberikan imbalan materi, tetapi juga memberikan perhatian dan penghargaan, maka dengan sendirinya gairah bekerja akan meningkat.

b) Teori kebutuhan Prestasi David Mc. Chelland

Menurut Mb. Chelland, kecenderungan seseorang dalam menghadapi pekerjaan, ingin secepatnya menyelesaikan tugas agar hasilnya secepat mungkin dapat dilihat. Lembih lanjut dikatakan bahwa kecenderungan untuk secepatnya menikmati hasil kerja sangat menonjol. Begitu sebaliknya, ada kecenderungan untuk menghindari kegagalan dari usahanya.

Dalam hubungan dengan teori Maslow, berarti motivasi ini terkait dengan ke- butuhan pada urutan tinggi, terutama kebutuhan aktualisasi diri dan kebutuhan akan status dan kekuasaan.

c) Teori pengharapan Victor H. Vroom Vroom menjelaskan bahwa motivasi merupakan suatu produk dari bagaimana seseorang menginginkan sesuatu dan penaksiran seseorang memungkinkan aksi tertentu yang akan menuntutnya.

d) Teori Motivasi Proses

Teori proses ini menjelaskan dan menggambarkan proses tentang bagaimana perilaku didorong, diarahkan, dipertahankan dan akhirnya dihentikan artinya bagaimana motivasi itu timbul.

\section{Produktivitas}

Masalah produktivitas adalah masalah yang sangat penting, apalagi untuk saat ini. Manusia semakin sadar bahwa produktivitas dapat meningkatkan kesejahteraan hidup manusia. Meskipun demikian belum ada persamaan dalam mengartikan produktivitas. Hal ini disebabkan makin berkembangnya konsep produksi dan banyaknya definisi yang diberikan oleh para ahli.

Secara umum produktivitas mengandung pengertian perbandingan antara hasil yang dicapai (output) dengan keseluruhan sumber daya yang digunakan (input), untuk itu penulis mengutip pendapat para ahli mengenai produktivitas sebagai berikut :

"Suatu pendekatan interdisipliner untuk menentukan tujuan yang efektif dengan menggunakan sumber-sumber secara efisien dengan tetap menjaga adanya kualitas yang tinggi”. Sedangkan Paulmali yang dikutip Sadarmayanti (2001:57) mendefinisikan sebagai berikut : "Produktivitas adalah bagaimana penghasilan atau meningkatkan hasil barang dan jasa setinggi mungkin dan memanfaatkan sumber daya secara efisien".

Dalam melakukan suatu pekerjaan, seorang karyawan hendaknya memiliki produk- 
tivitas kerja yang tinggi. Akan tetapi hal tersebut sulit dicapai, bahkan banyak karyawan yang memiliki produktivits yang rendah atau semakin menurun walaupun telah banyak memiliki pengalaman kerja dan perusahaan telah melaksanakan pelatihan ataupun pengembangan sumber daya manusianya untuk meningkatkan kemampuan dan motivasi kerja karyawan tersebut.

Produktivitas menurut Hasibuan (2001:94) menjelaskan sebagai berikut "Produktivitas kerja adalah perbandingan antara output dengan input dimana outputnya harus mempunyai nilai tambah dan teknik pengerjaannya yang lebih baik.

Dari pendapat diatas dapat disimpulkan bahwa secara umum produktivitas merupakan perbandingan antara hasil yang dicapai (output) dengan keseluruhan sumber daya yang digunakan (input). Dengan kata lain produktivitas memiliki dua dimensi. Dimensi pertama adalah efektivitas yang mengarah pada pencapaian untuk kerja yang maksimal, pencapaian target yang berkaitan dengan kualitas, kuantitas, dan waktu yang kedua yaitu efisiensi yang berkaitan dengan upaya membandingkan input dengan realisasi penggunaannya atau bagaimana pekerjaan tersebut dilaksanakan.

\section{METODOLOGI PENELITIAN}

\section{Ruang Lingkup Penelitian}

\section{Tempat Penelitian}

Penelitian ini dilaksanakan di PT. USAHA TEKNIK INDONESIA jalan LAPAN - Suradita No. 5 Cisauk - Tangerang 15343.

\section{Sifat Penelitian}

Sifat penelitian ini adalah bersifat kuantitatif dimana data kuantitatif adalah data yang bersifat terstruktur atau berpola sehingga ragam data yang diperoleh dari sumbernya (responden yang ditanyai atau objek yang diamati) cenderung memiliki pola yang lebih mudah dibaca oleh peneliti.

\section{Variabel Penelitian}

a. Variabel bebas (Variabel X) dalam penelitian ini adalah Motivasi.

b. Variabel Terikat (Variabel Y) dalam penelitian ini adalah Produktivitas Kerja Karyawan.

\section{Metode Penentuan Populasi dan Sampel}

\section{Populasi Penelitian}

Menurut Asep Hermawan (2009:145) populasi adalah seluruh kelompok orang, peristiwa atau benda yang menjadi pusat perhatian peneliti untuk diteliti. Sedangkan menurut Sugiyono (2011:82) pengertian populasi adalah wilayah generalisasi yang terdiri atas: obyek/subyek yang mempunyai kualitas dan karakteristik tertentu yang ditetapkan oleh peneliti untuk dipelajari dan kemudian ditarik kesimpulannya. Adapun populasi atau jumlah keseluruhan karyawan di PT. Usaha Teknik Indonesia pada tahun 2016 adalah 161 orang.

\section{Sampel Penelitian}

Sampel menurut Sugiyono, (2011:81) sampel adalah bagian dari jumlah dan karakteristik yang dimiliki oleh populasi. Menurut Arikunto (1998:73) yang mengatakan : "Apabila subjeknya kurang dari 100 orang lebih baik diambil semua sehingga penelitiannya merupakan penelitian populasi. Maka pada penelitian ini untuk menentukan sampel digunakan rumus sebagai berikut :

$$
\mathrm{n}=\frac{\mathrm{N}}{1+\mathrm{N}(\mathrm{e})^{2}}
$$

Adapun tingkat kesalahan yang akan digunakan dalam penarikan sampel adalah $10 \%$. Dengan Jumlah populasi (N) sebesar 161 orang, maka dapat diperoleh besarnya sampel sebagai berikut:

$$
\begin{aligned}
& \mathrm{n}=\frac{161}{1+161(0,1)^{2}} \\
& \mathrm{n}=61 \text { Orang }
\end{aligned}
$$


Dari perhitungan diatas dapat diketahui jumlah sampel (n) sebanyak 61 orang.

\section{Metode Pengumpulan Data}

Metode pengumpulan data, untuk tujuan yang telah ditetapkan dalam penelitian ini digunakan metode analisis deskriptif, kualitas dengan data kuantitafif yang dijabarkan dalam bentuk pertanyaan yang merupakan hasil dari analisis data yang telah dikelolah.

Metode yang penulis gunakan untuk penulisan ini adalah melalui studi pustaka (library research) dan studi lapangan (field research). Untuk teknis pelaksanaan penelitian lapangan guna memperoleh data

\section{Metode Analisis Data}

Untuk menganalisis pengaruh Motivasi terhadap Produktivitas Kerja Karyawan khususnya PT Usaha Teknik Indonesia, maka data yang diperoleh dari hasil kuesioner dianalisis dengan metode kuantitatif, yang mempunyai ciri dapat dinilai dengan menggunakan angka.

Untuk keperluan analisis kuantitatif, maka jawaban setiap item instrumen yang menggunakan skala likert dari kuesioner ini dapat diberi skor sebagai berikut:

\section{Kategori jawaban responden}

\begin{tabular}{|l|c|}
\multicolumn{1}{|c|}{ Jawaban } & Skor \\
\hline Sangat Setuju ( SS ) & 5 \\
\hline Setuju ( S ) & 4 \\
\hline Ragu - ragu ( RG ) & 3 \\
\hline Tidak Setuju ( TS ) & 2 \\
\hline Sangat tidak setuju ( STS ) & 1 \\
\hline
\end{tabular}

Sumber : Sugiyono (2011:94)

Sedangkan metode analisis data yang dipergunakan dalam penelitian ini sebagai berikut :

\section{Uji Validasi}

Uji validasi merupakan pengujian yang ditunjukan untuk mengetahui apakah terdapat kesamaan antara data yang terkumpul dengan data yang sesungguhnya terjadi pada objek yang diteliti.
Sugiyono (2011:348) Validasi menunjukan sejauh mana ketepatan dan kecermatan suatu alat ukur dalam melakukan fungsi ukurannya. Untuk menguji validitas kuesioner penelitian, formula yang dipaki adalah pearson's product moment.

$$
r=\frac{n \sum X Y-\sum X \cdot \sum Y}{\sqrt{ }\left\{N \sum x^{2}-\left(\sum x\right)^{2}\right\} \cdot\left\{N \sum y^{2}-\left(\sum y\right)^{2}\right\}}
$$

Dengan ketentuan uji validitasnya adalah :

a. Apabila $r$ hitung $>$ tabel (pada taraf signifikan 5\%), maka dapat dikatakan valid.

b. Apabila $r$ hitung $<$ tabel (pada taraf signifikan 5\%), maka dapat dikatakan tidak valid.

\section{Uji Reliabilitas}

Apabila alat ukur telah dinyatakan valid, langkah selanjutnya adalah menguji realibilitas alat ukur tersebut. Reliabilitas adalah satu nilai yang menunjukan konsistensi suatu alat ukur dalam mengukur gejala yang sama. Uji realibilitas pada alat ukur perlu dilakukan untuk memastikan instrumen dari alat ukur yang digunakan didalam penelitian ini konsisten dan akurat. Uji reliabilitas digunakan untuk menunjukan sejauh mana hasil pegukuran relative konsisten apabila pengukuran diulang dua kali atau lebih.

Hermawan (2006.126) reliabilitas berkaitan dengan konsistensi, akurasi dan prediktabilitas suatu alat ukur. cara yang digunakan untuk menguji reliabilitas kuesioner adalah dengan menggunakan rumus Cronbach Alpha yang dapat diartikan sebagai hubungan positif antar item/pertanyaan satu dengan yang lainnya.

$$
\mathrm{r}=\left|\frac{\mathrm{K}}{(\mathrm{k}-1)}\right|\left|1-\frac{\sum \mathrm{ó}^{2}}{\mathrm{ot}^{2}}\right|
$$

Dengan ketentuan uji validitas adalah:

a. Apabila $\mathrm{r}$ ca $>$ r tabel (pada taraf signifikan 5\%) maka dapat dikatakan reliabel. 
b. Apabila r ca $\leq \mathrm{r}$ tabel ( pada taraf signifikan 5\% ) maka dapat dikatakan tidak reliabel.

\section{Analisis Koefisien Korelasi (Product Mo- ment Pearson)}

Untuk dapat memberikan interprestasi seberapa kuat hubungan antara variabel $\mathrm{X}$ dan $\mathrm{Y}$ maka digunakan analisis korelasi product moment. W.Gulo (2002:181) Korelasi product moment pearson adalah statistic yang mengukur keserasian hubungan diantara dua variabel yang masing - masing diukur pada skala internal atau rasio, dengan asumsi bahwa variabel itu terdistribusi menurut distribusi normal. Untuk mengetahui hubungan antara variabel $\mathrm{X}$ dan variabel Y, maka digunakan analisis korelasi product moment dengan formula sebagai berikut:

$$
\mathrm{rxy}=\frac{\mathrm{n} \sum \mathrm{XX}-\sum \mathrm{x} \cdot \sum \mathrm{y}}{\sqrt{ }\left\{\mathrm{n} \sum \mathrm{x}^{2}-\left(\sum \mathrm{x}\right)^{2}\right\} \cdot\left\{\mathrm{n} \sum \mathrm{y}^{2}-\left(\sum \mathrm{y}\right)^{2}\right\}}
$$

Dengan ketentuan sebagai berikut:

a. $\mathrm{r}=1$ atau mendekati -1 , Maka hubungan variabel $\mathrm{X}$ dan $\mathrm{Y}$ dinyatakan kuat atau positif

b. $\quad r=0$ atau mendekati 0 , maka hubungan variabel $\mathrm{X}$ dan $\mathrm{Y}$ dinyatakan lemah atau tidak ada pengaruh

Untuk dapat memberikan penasiran terhadap koefisien korelasi ( $r$ ) yang ditemukan tersebut besar/kecil, maka dapat berpedoman pada ketentuan untuk memberikan interprestasi terhadap koefisien korelasi berdasarkan Sugiyono (2011:184) sebagai berikut:

Interprestasi nilai koefisien korelasi

\begin{tabular}{|c|c|}
\hline $\begin{array}{c}\text { Interval Koefisien } \\
0,00-0,199\end{array}$ & $\begin{array}{c}\text { Tingkat Hubungan } \\
\text { Sangat Rendah }\end{array}$ \\
\hline $0,20-0,399$ & Rendah \\
\hline $0,40-0,599$ & Sedang \\
\hline $0,60-0,799$ & Kuat \\
\hline $0,80-1,000$ & Sangat Kuat \\
\hline
\end{tabular}

Sumber : Sugiyono (2011:184)

\section{Koefisien Determinasi}

Menurut J. Suprapto (2008:5) Koefisien determinasi adalah bagian dari keragaman total variabel Y (terikat) yang dapat diterangkan atau diperhitungkan oleh keragaman variable X (bebas) yaitu koefisien yang mengukur besarnya persentase kontribusi X terhadap Y.

Untuk mengetahui seberapa besar pengaruh motivasi terhadap produktifitas kerja karyawan, dapat menggunakan rumus koefisien determinasi atau koefisien penentu sebagai berikut :

$$
R=r^{2} \times 100 \%
$$

$\mathrm{R}$ = mengukur besarnya jumlah reduksi dalam variable dependen yang diperoleh dari penggunaan variable bebas. $\mathrm{R}$ mempunyai nilai antara 0 sampai 1 , dengan nilai $\mathrm{R}$ tinggi berkisar 0,8 sampai 1 . $\mathrm{R}$ yang digunakan adalah nilai adjusted $\mathrm{R}$ yang telah disesuaikan. Adjusted $\mathrm{R}$ merupakan indicator untuk mengetahui pengaruh perkembangan variable independen ke dalam persamaan.

\section{Uji Signifikan ( Uji-T)}

Untuk mengetahui apakah hubungan antara variabel bebas mempunyai pengaruh yang nyata atau tidak terhadap variabel terikat, maka dilakukan Uji hipotesis. Bentuk pengujiannya adalah sebagai berikut :

Ho: $=0$; Artinya tidak terdapat pengaruh yang signifikan antara variabel $\mathrm{X}$ dengan variabel $\mathrm{Y}$.

$\mathrm{Ha}: \neq 0$; Artinya ada pengaruh yang signifikan antara variabel $\mathrm{X}$ dengan variabel $\mathrm{Y}$.

Selanjutnya untuk mengetahui signifikansi dari setiap variabel independen terhadap variabel terikat, maka dilakukan Uji t, yang sebagaimana dikemukakan oleh Sugiyono (2011:184 dengan rumus :

$$
t=\frac{r \sqrt{n-2}}{\sqrt{1-r^{2}}}
$$

Keterangan :

$\mathrm{t}=$ nilai $\mathrm{t}$ yang dihitung selanjutnya disebut thitung 
$\mathrm{r}=$ koefisien korelasi

$\mathrm{n}=$ jumlah responden

Kriteria pengujian adalah :

a. Apabila nilai thitung $>$ ttabel pada taraf signifikan 5\% maka H0 ditolak dan H1 diterima. Artinya terdapat pengaruh yang signifikan antara motivasi terhadap produktivitas kerja karyawan.

b. Apabila nilai thitung $<$ ttabel pada taraf signifikan 5\% maka $\mathrm{H} 1$ ditolak dan $\mathrm{H} 0$ diterima. Artinya terdapat pengaruh yang signifikan antara motivasi terhadap produktivitas kerja karyawan

\section{Operasional Variabel Penelitian}

Opersional variabel adalah suatu unsur penelitian bagaimana cara mengukur suatu variabel, baik variabel bebas maupun variabel terikat.

Menurut Sugiyono (2011:38) variabel penelitian adalah segala sesuatu yang berbentuk apa saja yang ditetapkan oleh peneliti untuk dipelajari sehingga diperoleh informasi tentang hal tersebut, kemudian ditarik kesimpulannya. Dalam penelitian ini motivasi merupakan variabel bebas (X) dan produktivitas kerja karyawan merupakan variabel terikat (Y). Indikatorindikator variabel sebagai berikut :

\section{Operasional Variabel Penelitian}

\begin{tabular}{|c|ll|c|c|}
\hline Variabel & & Indikator & $\begin{array}{c}\text { No. Butir } \\
\text { Kuesioner }\end{array}$ & Skala \\
& 1. & Kemauan/ & $1,2,3$ & \\
Motivasi (X) & & Keinginan & 4,5 & \\
& 2. & Semangat & 6,7 & Likert \\
& 3. & Kebutuhan & $8,9,10$ & \\
& 4. & Tujuan & & \\
\hline & 1. & Sikap dan etika & $1,2,3$ & \\
Produktivitas & 2. & Disiplin & 4,5 & \\
Kerja Karyawan & 3. & Loyalitas & 6,7 & Likert \\
(Y) & 4. & Inovasi & $8,9,10$ & \\
\hline
\end{tabular}

\section{HASIL PENELITIAN}

Bengkel Bubut dan Las PT Usaha Teknik Indonesia didirikan pada tanggal 27 Februari 2000 dengan fasilitas tempat, peralatan dan karyawan yang masih sangat terbatas. Pada awalnya, usaha ini hanya bergerak dibidang jasa reparasi, konstruksi, bubut dan perbaikan bak besi dan hydraulic, tetapi seiring meningkatnya permintaan konsumen yang begitu besar akan kebutuhan karoseri, utamanya bak besi, dump truk dan tangka, maka dipandang perlu untuk melebarkan sayap guna memenuhi permintaan pasar tersebut. Untuk merelalisasikan hal tersebut diatas, dengan persiapan fasilitas tempat dan peralatan yang relative lebih baik serta didukung oleh beberapa pihak, maka pada tanggal 08 Februari 2012, PT USAHA TEKNIK INDONESIA resmi didirikan.

\section{Deskriptif Hasil Penelitian}

Dalam penelitian ini populasi yang digunakan adalah karyawan PT. Usaha Teknik Indonesia yang berjumlah 161 orang dengan sampel yang diambil 61 orang, penelitian ini bertujuan untuk mengetahui seberapa besar pengaruh motivasi kerja terhadap produktivitas kerja karyawan pada PT. Usaha Indonesia. Untuk mengetahui hal tersebut maka penelitian melakukan penyebaran kuesioner sebanyak 61 orang. Setelah kuesinoner disebar ke karyawan maka peneliti memperoleh karakteristik responden sebagai berikut :

a. Jenis kelamin responden

Berdasarkan kuesioner yang di sebar, maka diperoleh jenis kelamin responden dalam penelitian ini dapat diklasifikasikan sebagai berikut :

\begin{tabular}{c|c|c|}
\multicolumn{2}{c}{ Klasifikasi Responden Menurut } \\
Jenis Kelamin \\
\hline \multirow{2}{*}{ Jenis Kelamin } & \multicolumn{2}{|c|}{ Jumlah Responden } \\
\cline { 2 - 3 } & Dalam Angka & Dalam Persentase \\
\hline Laki - laki & 43 & $70,50 \%$ \\
\hline Perempuan & 18 & $29,50 \%$ \\
\hline Jumlah & $\mathbf{6 1}$ & $\mathbf{1 0 0 , 0 0 \%}$ \\
\hline
\end{tabular}

Sumber : Data yang diolah

Dari data tabel diatas menunjukan bahwa karyawan laki-laki lebih banyak dibutuhkan dari pada karyawan perempuan dalam melakukan kegiatan operasional, karena jumlah karyawan laki - laki lebih banyak yaitu 70,50\% dari karyawan perempuan yaitu $29,50 \%$. 


\section{b. Usia Responden}

Berdasarkan data yang didapat, maka usia responden dalam penelitian ini dapat diklasifikasikan sebagai berikut :

\section{Klarifikasi Responden Menurut Usia}

\begin{tabular}{|c|c|c|}
\hline \multirow{2}{*}{ Usia (Tahun) } & \multicolumn{2}{|c|}{ Jumlah Responden } \\
\cline { 2 - 3 } & Dalam Angka & Dalam Persentase \\
\hline$<25$ & 15 & $24.60 \%$ \\
\hline $26-35$ & 25 & $40,98 \%$ \\
\hline $36-45$ & 12 & $19,67 \%$ \\
\hline$>45$ & 9 & $14,75 \%$ \\
\hline Jumlah & $\mathbf{6 1}$ & $\mathbf{1 0 0 , 0 0 \%}$ \\
\hline
\end{tabular}

Berdasarkan tabel diatas menunjukkan bahwa sebagian besar karyawan berusia antara 26 - 35 atau usia produktif, maka dapat disimpulkan bahwa perusahaan PT. Usaha Teknik Indonesia lebih membutuhkan tenaga muda karena membutuhkan tenaga yang cukup besar dalam melakukan operasional kegiatannya. Sedangkan usia yang mendekati pensiun hanya $14,75 \%$.

c. Lama kerja responden

Klasifikasi Responden Menurut Lama Kerja

\begin{tabular}{|c|c|c|}
\multirow{2}{*}{ Lama Kerja } & \multicolumn{2}{|c|}{ Jumlah Responden } \\
\cline { 2 - 3 } & Dalam Angka & Dalam Persentase \\
\hline$<5$ tahun & 21 & $34,42 \%$ \\
\hline$>5$ tahun & 40 & $65,58 \%$ \\
\hline Jumlah & $\mathbf{6 1}$ & $\mathbf{1 0 0 , 0 0 \%}$ \\
\hline
\end{tabular}

Sumber : Data yang diolah

Dari data tabel 4.3 diatas menunjukkan bahwa karyawan yang bekerja kurang dari 5 tahun sebesar $34,42 \%$, sedangkan yang lebih dari 5 tahun ada $65,58 \%$. Maka dapat disimpulkan karyawan yang dimiliki PT. Usaha Teknik Indonesia merupakan karyawan lama dan cukup berpengalaman.

\section{d. Tingkat pendidikan responden}

Berdasarkan tingkat pendidikan terakhir yang ditempuh oleh responden, maka dalam penelitian ini dapat diklasifikasikan sebagai berikut :

\section{Klasifikasi Responden Menurut} Tingkat Pendidikan

\begin{tabular}{|c|c|c|}
\multirow{2}{*}{$\begin{array}{c}\text { Pendidikan } \\
\text { Terakhir }\end{array}$} & \multicolumn{2}{|c|}{ Jumlah Responden } \\
\cline { 2 - 3 } & Dalam Angka & Dalam Persentase \\
\hline SMA & 38 & $62,30 \%$ \\
\hline D3 & 13 & $21,31 \%$ \\
\hline S1 & 8 & $13,11 \%$ \\
\hline S2 & 2 & $3,28 \%$ \\
\hline Jumlah & $\mathbf{6 1}$ & $\mathbf{1 0 0 , 0 0 \%}$ \\
\hline
\end{tabular}

Berdasarkan data pada tabel 4.4 diatas diketahui bahwa tingkat pendidikan karyawan pada PT. Usaha Teknik Indonesia rata - rata merupakan lulusan SMA yaitu 38 orang atau $62,30 \%$, lulusan D3 sebesar 21,31\%, sarjana atau strata 1 (S1) 13,11\%, sedangkan (S2) sebesar 3,28, Maka dapat disimpulkan bahwa pada PT Usaha Teknik Indonesia Tingkat pendidikan karyawan yang dibutuhkan tidak terlalu tinggi.

\section{Hasil dan Pembahasan Variabel Motivasi (X)}

Berdasarkan hasil dari penyebaran kuesioner yang dilakukan oleh peneliti pada 61 responden dengan 10 pernyataan dapat dijelaskan hasil jawaban responden mengenai motivasi. Seluruh pernyataan diambil dari jumlah kuesioner yang menjawab Sangat Setuju (SS) $=232$, Setuju (S) = 209, Ragu - Ragu $(R G)=169$, Tidak Setuju (TS) $=0$, dan Sangat Tidak Setuju (STS) = 0 Maka Jumlah keseluruhan hasil pernyataan adalah $=610$. Maka persentasenya adalah :

$$
\begin{aligned}
& \text { SS }=232: 610 \times 100 \%=38,04 \% \\
& S=209: 610 \times 100 \%=34,26 \% \\
& \text { RG }=169: 610 \times 100 \%=27,70 \% \\
& \text { TS }=0: 610 \times 100 \%=0 \\
& \text { STS }=0: 610 \times 100 \%=0
\end{aligned}
$$

Dilihat dari perhitungan diatas menunjukkan bahwa motivasi yang dialami oleh karyawan PT Usaha Teknik Indonesia mendapatkan respon yang cukup baik dari karyawan.

\section{Uji validitas Variabel Motivasi (X)}

Berikut ini akan disajikan langkah - langkah dalam melakukan uji validitas secara man- 
ual dengan cara Pearson's Product Moment pada variabel motivasi $(\mathrm{X})$ sebagaimana berikut

Diketahui Bahwa :

$$
\mathrm{N}=61 \sum \mathrm{X}=252 \quad \sum \mathrm{Y}=2503 \quad \sum \mathrm{X}^{2}=
$$
1082

$$
\begin{aligned}
& \sum \mathrm{Y}^{2}=103287 \sum \mathrm{XY}=10404 \\
& \mathrm{r}=\frac{\mathrm{n} \sum \mathrm{XY}-\left(\sum \mathrm{X} \cdot \sum \mathrm{Y}\right)}{\left.\sqrt{\{N} \sum \mathrm{x}^{2}-\left(\sum \mathrm{x}\right)^{2}\right\} \cdot\left\{\mathrm{N} \sum \mathrm{y}^{2}-\left(\sum \mathrm{y}\right)^{2}\right\}} \\
& \mathrm{r}=0,41288
\end{aligned}
$$

Berdasarkan perhitungan diatas dapat diketahui bahwa r-hitung $(0,41288)>\mathrm{t}$-tabel $(0,242)$, dengan ketentuan $a=5 \%$ yang berarti pertanyaan nomor satu dinyatakan valid. Untuk pernyataan nomor 2 sampai 10 dapat menggunakan cara yang sama. Maka rangkuman analisis validitas dapat dilihat di tabel 4.7 berikut :

\section{Tabel 4.8}

Rangkuman Analisis Validitas Variabel
\begin{tabular}{c|c|c|c|c|c|c|c|c|c|c|}
\hline $\begin{array}{c}\text { r } \\
\text { hitung }\end{array}$ & 0,412 & 0,451 & 0,398 & 0,483 & 0,302 & 0,339 & 0,391 & 0,367 & 0,398 & 0,413 \\
\hline r tabel & 0,242 & 0,242 & 0,242 & 0,242 & 0,242 & 0,242 & 0,242 & 0,242 & 0,242 & 0,242 \\
\hline Ket & Valid & Valid & Valid & Valid & Valid & Valid & Valid & Valid & Valid & Valid \\
\hline
\end{tabular}

\section{Uji Reliabilitas / Uji t Variabel Motivasi (X)}

Berikut ini akan disajikan langkah - langkah dalam melakukan uji reliabilitas secara manual dengan menggunakan rumus Cronbach Alpha pada variabel motivasi (X) sebagaimana berikut :

a. Menghitung Varians Butir

Contoh pada butir no 1

Diketahui :

$$
\begin{array}{ll}
\Sigma \mathrm{Xi}^{2} & =1082 \\
\Sigma \mathrm{Xi} & =252
\end{array}
$$

$$
\mathrm{Si}^{2}=\frac{1082\left(\frac{252}{61}\right)^{2}}{61}
$$

$\mathrm{Si}^{2}=\frac{1082-1041,0491}{61}$

$\mathrm{Si}^{2}=\frac{40,9509}{61}$

$\mathrm{Si}^{2}=0,67132$
Varians butiran item ke 2 sampai ke $10 \mathrm{da}$ pat dihitung dengan cara yang sama seperti perhitungan varians item pertama. Dengan demikian skor total varians tiap butirannya adalah :



b. Mencari Varians Total

Diketahui :

$\begin{array}{ll}\sum \mathrm{Xt}^{2} & =103287 \\ \Sigma \mathrm{Xt} & =2503 \\ \mathrm{~N}=61 & \end{array}$

$\mathrm{St}^{2}=\frac{\sum \mathrm{Xt}^{2}\left(\frac{\sum X t}{n}\right)^{2}}{\mathrm{n}}$

$\mathrm{St}^{2}=\frac{103287-\left(\frac{6265009}{61}\right)^{2}}{61}$

$\mathrm{St}^{2}=\frac{581,94}{61}$

$\mathrm{St}^{2}=9,54$

c. Mencari Reliabilitas Variabel

Diketahui :

$\begin{array}{ll}\Sigma \mathrm{Si}^{2} & =6,1515 \\ \Sigma \mathrm{Xt} & =9,5399\end{array}$

$\mathrm{K}=61$

$\mathrm{rca}=1-$

$\mathrm{rca}=$

$\mathrm{rca}=$

$\mathrm{rca}=$

$\mathrm{rca}=0,3611$

Kesimpulan :

Dari hasil perhitungan reliabilitas diatas menunjukkan bahwa varians butiran item variabel X dinyatakan reliabel karena $\mathrm{rca}>$ rtabel yaitu $0,3611>0,242$

\section{Hasil dan Pembahasan Variabel Produk- tivitas Kerja (Y)}

Berdasarkan hasil dari penyebaran kuesioner yang dilakukan oleh peneliti pada 61 
resonden dengan 10 pernyataan, maka data hasil kuesioner variabel produktivitas kerja karyawan dapat dilihat sebagai berikut,

Seluruh pernyataan diambil dari jumlah kuesioner yang menjawab Sangat Setuju (SS) $=262$, Setuju $(S)=176$, Ragu- ragu $(R G)=172$, Tidak Setuju (TS) =0, dan Sangat Tidak Setuju (STS) $=0$. Maka jumlah keseluruhan hasil pernyataan adalah $=610$. Maka persentasenya adalah :

$$
\begin{array}{lr}
\text { SS } & =262: 610 \times 100 \%=42,95 \% \\
\text { S } & =176: 610 \times 100 \%=28,85 \% \\
\text { RG }=172: & 610 \times 100 \%=28,20 \% \\
\text { TS } & =0: 610 \times 100 \%=0 \\
\text { STS } & =0: 610 \times 100 \%=0
\end{array}
$$

Dilihat dari perhitungan tabel 4.10 diatas menunjukkan bahwa produktivitas kerja pada karyawan PT Usaha Teknik Indonesia mendapatkan respon yang cukup baik oleh karyawan dengan rincian jawaban dari 10 pernyataan sejumlah 610 dari 61 responden sebagai berikut: 262 atau 42,95\% menjawab Sangat Setuju, 176 atau 28,85\% menjawab Setuju, 172 atau 28,19\% menjawab Ragu-Ragu, 0\% menjawab Tidak Setuju dan 0\% menjawab Sangat Tidak Setuju.

\section{Uji Validitas Variabel Produktivitas Kerja (Y)}

Berikut ini akan disajikan langkah - langkah dalam melakukan uji validitas secara manual dengan cara Pearson's Product Moment pada variabel produktivitas kerja (Y) sebagaimana diketahui Bahwa :

$$
\begin{aligned}
& \mathrm{N}=61 \sum \mathrm{X}=263 \quad \sum \mathrm{Y}=2503 \quad \sum \mathrm{X}^{2}=1171 \\
& \sum \mathrm{Y}^{2}=105632 \sum \mathrm{XY}=10980 \\
& \mathrm{r}=\frac{\mathrm{n} \sum \mathrm{XY}-\sum \mathrm{X} \cdot \Sigma \mathrm{Y}}{\left.\sqrt{\{N} \sum \mathrm{x}^{2}-\left(\sum \mathrm{x}\right)^{2}\right\} \cdot\left\{\mathrm{N} \sum \mathrm{y}^{2}-\left(\sum \mathrm{y}\right)^{2}\right\}} \\
& \mathrm{r}=\frac{(61.10980)-(263.2530)}{\sqrt{(61.1171)}-(263)^{2} \cdot(61.105632)-} \\
& \mathrm{r}=\frac{(2530)^{2}(669780)-(665390)}{\sqrt{9822,363}} \\
& \mathrm{r}=0,446939
\end{aligned}
$$

Berdasarkan perhitungan diatas dapat diketahui bahwa r-hitung $(0,446939)>\mathrm{t}$-tabel $(0,242)$, dengan ketentuan $a=5 \%$ yang berarti pernyataan no satu dinyatakan valid. Untuk pernyataan no 2-10 dapat menggunakan cara yang sama. Maka rangkuman analisis validitas dapat dilihat di tabel berikut :

\section{Rangkuman Analisis Validitas Variabel Produktivitas Kerja (Y)}

\begin{tabular}{|l|c|c|c|c|c|c|c|c|c|}
\hline 0.447 & 0.561 & 0.446 & 0.458 & 0.305 & 0.495 & 0.321 & 0.469 & 0.299 & 0.403 \\
\hline 0,242 & 0,242 & 0,242 & 0,242 & 0,242 & 0,242 & 0,242 & 0,242 & 0,242 & 0,242 \\
\hline Valid & Valid & Valid & Valid & Valid & Valid & Valid & Valid & Valid & Valid \\
\hline
\end{tabular}

\section{Uji Reliabilitas / Uji t Variabel Produk- tivitas Kerja (Y)}

Berikut ini akan disajikan langkah-langkah dalam melakukan uji reliabilitas / uji t secara manual dengan menggunakan rumus Cronbach Alpha pada variabel produktivitas kerja (Y) sebagaimana berikut :

a. Menghitung Varians Butir

Contoh pada butir no 1

Diketahui :

$\begin{array}{ll}\sum \mathrm{Xi}^{2} & =1171 \\ \sum \mathrm{Xi} & =263\end{array}$

$\mathrm{Si}^{2}=\frac{1171\left(\frac{263}{61}\right)^{2}}{61}$

$\mathrm{Si}^{2}=\frac{37,082}{61}$

$\mathrm{Si}^{2}=0,607901$

Varians butir item ke 2 sampai ke 10 dapat dihitung dengan cara yang sama seperti perhitungan varians item pertama. Dengan demikian skor total varians tiap butirnya adalah :

\begin{tabular}{|l|l|l|l|l|l|l|l|l|l|l|l|l|}
\hline b/Si & 0.6073 & 0.6842 & 0.5358 & 0.7046 & 0.6100 & 0.5735 & 0.6052 & 0.7116 & 0.7116 & 0.7497 & $\Sigma \mathrm{Si}$ & 6.4944 \\
\hline
\end{tabular}

Mencari Varians Total

Diketahui :

$\begin{array}{ll}\Sigma \mathrm{Xt}^{2} & =105632 \\ \Sigma \mathrm{Xt} & =2530 \\ \mathrm{~N} & =61\end{array}$


$\mathrm{St}^{2}=\frac{\sum \mathrm{Xt}^{2}\left(\frac{\sum X t}{n}\right)^{2}}{\mathrm{n}}$

$\mathrm{St}^{2}=\frac{105632-\left(\frac{2530}{61}\right)^{2}}{61}$

$\mathrm{St}^{2}=\frac{699,22}{61}$

$\mathrm{St}^{2}=11,4626$

c. Mencari Reliabilitas Variabel

Diketahui :

$$
\begin{aligned}
& \sum \mathrm{Si}^{2} \quad=6,494491 \\
& \sum \mathrm{Xt}=11,46251 \\
& \mathrm{~K}=61 \\
& \mathrm{rca}=\left|\frac{K}{(K-1)}\right|\left|1-\frac{\sum S i^{2}}{S t^{2}}\right| \\
& \mathrm{rca}=\left|\frac{61}{(61-1)}\right|\left|1-\frac{6,49449}{11,46251}\right| \\
& \mathrm{rca}=\left|\frac{61}{61}\right|[1-0,5665853] \\
& \mathrm{rca}=[1,0166666][0,4334147] \\
& \mathrm{rca}=0,4406
\end{aligned}
$$

Kesimpulan:

Dari hasil perhitungan reliabilitas diatas menunjukan bahwa varians butiran 1 item variabel Y dinyatakan reliabel karena rca > rtabel yaitu $0,4406>0,242$.

\section{Analisis Koefisien Korelasi}

Dalam menganalisa hubungan motivasi terhadap produktivitas kerja karyawan, maka penulis menggunakan metode korelasi sederhana. Dari hasil pengumpulan kuesioner sebanyak 61 responden dengan 10 pernyataan dalam variabel motivasi $(\mathrm{X})$ dan variabel produktivitas kerja (Y) diperoleh data sebagai berikut :
Tabel 4.13

Analisis Pengaruh Variabel X - Y

\begin{tabular}{c|c|c|c|c|c} 
No & $\mathbf{X}$ & $\mathbf{Y}$ & $\mathbf{X}^{\mathbf{2}}$ & $\mathbf{Y}^{\mathbf{2}}$ & $\mathbf{X Y}$ \\
\hline
\end{tabular}

\begin{tabular}{|c|c|c|c|c|c|}
\hline 1 & 39 & 37 & 1521 & 1369 & 1443 \\
\hline 2 & 40 & 37 & 1600 & 1369 & 1480 \\
\hline 3 & 43 & 41 & 1849 & 1681 & 1763 \\
\hline 4 & 39 & 39 & 1521 & 1521 & 1521 \\
\hline 5 & 42 & 39 & 1764 & 1521 & 1638 \\
\hline 6 & 40 & 42 & 1600 & 1764 & 1680 \\
\hline
\end{tabular}

\begin{tabular}{|l|l|l|l|l|l|l|}
\hline 6 & 40 & 42 & 1600 & 1764 & 1680 \\
\hline 7 & 45 & 44 & 2025 & 1936 & 1980
\end{tabular}

\begin{tabular}{|l|l|l|l|l|l|}
\hline 7 & 45 & 44 & 2025 & 1936 & 1980 \\
\hline 8 & 41 & 43 & 1681 & 1849 & 1763 \\
\hline
\end{tabular}

\begin{tabular}{|l|l|l|l|l|l|}
\hline 9 & 44 & 43 & 1936 & 1849 & 1892 \\
\hline 10 & 45 & 46 & 2025 & 216 & 2070 \\
\hline
\end{tabular}

\begin{tabular}{|l|l|l|l|l|l|}
\hline 10 & 45 & 46 & 2025 & 2116 & 2070 \\
\hline 11 & 45 & 46 & 2025 & 2116 & 2070 \\
\hline
\end{tabular}

\begin{tabular}{|l|l|l|l|l|l|}
\hline 12 & 41 & 41 & 1681 & 1681 & 1681 \\
\hline 13 & 41 & 46 & 1681 & 2116 & 1886 \\
\hline
\end{tabular}

\begin{tabular}{|l|l|l|l|l|l|}
\hline 14 & 38 & 38 & 1444 & 1444 & 1444 \\
\hline
\end{tabular}

\begin{tabular}{|l|l|l|l|l|l|l}
\hline 15 & 44 & 46 & 1936 & 2116 & 2024 \\
\hline 16 & 37 & 36 & 1369 & 1296 & 1332 \\
\hline
\end{tabular}

\begin{tabular}{|l|l|l|l|l|l|}
\hline 17 & 42 & 40 & 1764 & 1600 & 1680 \\
\hline 18 & 37 & 40 & 1369 & 1600 & 1480 \\
\hline
\end{tabular}

\begin{tabular}{|r|r|r|r|r|r|}
\hline 19 & 40 & 39 & 1600 & 1521 & 1560 \\
\hline 20 & 39 & 41 & 1521 & 1681 & 1599 \\
\hline
\end{tabular}

\begin{tabular}{|l|l|l|l|l|l|}
\hline 20 & 39 & 41 & 1521 & 1681 & 1599 \\
\hline 21 & 40 & 43 & 1600 & 1849 & 1720 \\
\hline 22 & 37 & 38 & 1369 & 1444 & 1406 \\
\hline 23 & 42 & 42 & 1764 & 1764 & 1764 \\
\hline 24 & 36 & 36 & 1296 & 1296 & 1296 \\
\hline 25 & 36 & 39 & 1296 & 1521 & 1404 \\
\hline 26 & 37 & 37 & 1369 & 1369 & 1369 \\
\hline 27 & 36 & 38 & 1296 & 1444 & 1368 \\
\hline 28 & 43 & 40 & 1849 & 1600 & 1720 \\
\hline 29 & 39 & 37 & 1521 & 1369 & 1443 \\
\hline 30 & 37 & 36 & 1369 & 1296 & 1332 \\
\hline 31 & 46 & 44 & 2116 & 1936 & 2024 \\
\hline 32 & 43 & 46 & 1849 & 2116 & 1978 \\
\hline 33 & 40 & 46 & 1600 & 2116 & 1840 \\
\hline 34 & 42 & 42 & 1764 & 1764 & 1764 \\
\hline 35 & 41 & 42 & 1681 & 1764 & 1722 \\
\hline 36 & 39 & 42 & 1521 & 1764 & 1638 \\
\hline 37 & 39 & 39 & 1521 & 1521 & 1521 \\
\hline 38 & 42 & 42 & 1764 & 1764 & 1764 \\
\hline 39 & 45 & 45 & 2025 & 2025 & 2025 \\
\hline 40 & 37 & 37 & 1369 & 1369 & 1369 \\
\hline 41 & 40 & 40 & 1600 & 1600 & 1600 \\
\hline
\end{tabular}




\begin{tabular}{|c|c|c|c|c|c|}
\hline No & $\mathbf{X}$ & $\mathbf{Y}$ & $\mathbf{X}^{\mathbf{2}}$ & $\mathbf{Y}^{\mathbf{2}}$ & $\mathbf{X Y}$ \\
\hline 42 & 37 & 39 & 1369 & 1521 & 1443 \\
\hline 43 & 39 & 39 & 1521 & 1521 & 1521 \\
\hline 44 & 44 & 44 & 1936 & 1936 & 1936 \\
\hline 45 & 40 & 41 & 1600 & 1681 & 1640 \\
\hline 46 & 43 & 41 & 1849 & 1681 & 1763 \\
\hline 47 & 40 & 40 & 1600 & 1600 & 1600 \\
\hline 48 & 43 & 43 & 1849 & 1849 & 1849 \\
\hline 49 & 38 & 38 & 1444 & 1444 & 1444 \\
\hline 50 & 37 & 37 & 1369 & 1369 & 1369 \\
\hline 51 & 46 & 44 & 2116 & 1936 & 2024 \\
\hline 52 & 43 & 41 & 1849 & 1681 & 1763 \\
\hline 53 & 44 & 42 & 1936 & 1764 & 1848 \\
\hline 54 & 39 & 39 & 1521 & 1521 & 1521 \\
\hline 55 & 47 & 44 & 2209 & 1936 & 2068 \\
\hline 56 & 49 & 45 & 2401 & 2025 & 2205 \\
\hline 57 & 44 & 48 & 1936 & 2304 & 2112 \\
\hline 58 & 39 & 47 & 1521 & 2209 & 1833 \\
\hline 59 & 45 & 47 & 2025 & 2209 & 2115 \\
\hline 60 & 43 & 48 & 1849 & 2304 & 2064 \\
\hline 61 & 44 & 48 & 1936 & 2304 & 2112 \\
\hline$\Sigma$ & $\mathbf{2 5 0 3}$ & $\mathbf{2 5 3 0}$ & $\mathbf{1 0 3 2 8 7}$ & $\mathbf{1 0 5 6 3 2}$ & $\mathbf{1 0 4 2 8 3}$ \\
\hline
\end{tabular}

Dari data diatas, untuk mengetahui pengaruh antara variabel $\mathrm{X}$ dengan variabel $\mathrm{Y}$ penulis menggunakan rumus korelasi. Dan berikut adalah cara perhitungannya :

Diketahui :

$$
\begin{aligned}
& \mathrm{N}=61 \sum \mathrm{X}=2503 \quad \sum \mathrm{Y}=2530 \sum \mathrm{X}^{2}=103287 \\
& \sum \mathrm{Y}^{2}=105632 \Sigma \mathrm{XY}=104283
\end{aligned}
$$$$
\mathrm{n} \Sigma \mathrm{XY}-\sum \mathrm{x} \cdot \sum \mathrm{y}
$$$$
\operatorname{rxy}=
$$$$
\left.\sqrt{\{N} \sum^{\mathrm{X}^{2}}-\left(\sum \mathrm{X}\right)^{2}\right\} .\left\{\mathrm{N} \sum \mathrm{y}^{2}-\left(\sum \mathrm{y}\right)^{2}\right\}
$$

$$
\begin{aligned}
& \operatorname{xxy}=\frac{(61.104283)-(2503.2530)}{} \sqrt{(61.103287)}-(2503)^{2} . \\
&(61.105632)-(2530)^{2}
\end{aligned}
$$$$
(6361263)-(6332590)
$$

$$
\begin{array}{r}
r x y=\frac{(\sqrt{(6300507-6265009)}}{(6443552-6400900)}
\end{array}
$$

28673

$$
\begin{aligned}
& r x y=\frac{\sqrt{(\text { üü }) \cdot(42652)}}{r x y=\frac{28673}{\sqrt{1514060696}}} \\
& r x y=0,737
\end{aligned}
$$

Berdasarkan hasil analisis diatas dengan menggunakan koefisien korelasi product moment maka didapat pengaruh yang Kuat antara variabel $\mathrm{X}$ dengan variabel $\mathrm{Y}$ yaitu sebesar 0,737.

\section{Koefisien Determinasi}

Setelah mengetahui koefisien korelasi maka selanjutnya untuk mengetahui seberapa besar kontribusi variabel $\mathrm{X}$ terhadap variabel $\mathrm{Y}$ digunakan rumus koefisien determinasi $(\mathrm{R})$ dengan rumus sebagai berikut:

$$
\begin{aligned}
& R=r^{2} \times 100 \% \\
& R=0,5431 \times 100 \% \\
& R=54,31 \%
\end{aligned}
$$

Dari hasil diatas membuktikan bahwa kontribusi motivasi terhadap produktivitas kerja adalah sebesar $54,31 \%$ dan sisanya $45,69 \%$ dipengaruhi oleh faktor - faktor lain.

\section{Uji Regresi Linier Sederhana}

Perhitungan Regresi Linier Sederhana

Diketahui :

$\mathrm{n}=61$

$\sum \mathrm{x}=2503$

$\sum \mathrm{y}=2530$

$\sum \mathrm{x}^{2}=103287$

$\sum \mathrm{xy}=104283$

$$
\begin{aligned}
& =\frac{61(104283)-(2503)(2530)}{61(103287)-(2503)^{2}} \\
\mathrm{~b} & =\frac{6361263-6332590}{6300507-6265009} \\
\mathrm{~b} & =\frac{\ddot{\mathrm{u}}}{\ddot{\mathrm{u}}} \\
\mathrm{b} & =0,807
\end{aligned}
$$




$$
\begin{aligned}
& a=\frac{2530}{61}-\frac{(0,807)(2503)}{61} \\
& a=41,47-33,11 \\
& a=8,36 \\
& y=8,36-0,807(X)
\end{aligned}
$$

Regresi linier sederhana di dapatkan persamaan artinya $\mathbf{Y}=\mathbf{8 , 3 6}+\mathbf{0 , 8 0 7}(\mathrm{X})$ artinya apabila variabel motivasi $\mathbf{1 \%}$ di tingkatkan maka mempengaruhi peningkatkan produktivitas kerja karyawan sebesar $\mathbf{0 , 8 0 7}$ dan sebaliknya apabila pemberian motivasi di turunkan $\mathbf{1 \%}$ maka akan terjadi penurunan produktivitas kerja karyawan sebesar $\mathbf{0 , 8 0 7}$

\section{Uji Signifikan (Keberatian) Regresi Li- nier Sederhana}

Berdasarkan hasil perhitungan diatas, maka peneliti melakukan pengujian hipotesa dengan cara membandingkan nilai t- tabel dengan t- hitung. Nilai t-tabel ditentukan berdasarkan tingkat signifikan (a) yang digunakan dan derajat kebesaran $(\mathrm{df}=2-\mathrm{n})$ yang besarnya tergantung dari jumlah sampel (N). Taraf nyata yang penulis gunakan sebesar 0,05 (5\%).

Karena pada tabel tidak ditemukan $\mathrm{dk}=61$ maka dapat dicari melalui perhitungan interpolasi sebagai berikut:

Diketahui : $\mathrm{t}(0,05 ; 60)=1,671$ (lihat tabel distribusi t pada lampiran)

$\mathrm{t}(0,05 ; 120)=1,658$ (lihat tabel distribusi $\mathrm{t}$ pada lampiran)

maka untuk dk 61 adalah :

$\mathrm{dk}=\mathrm{n}-2$

$\mathrm{dk}=61-2=59$

$=1,658+\left(\frac{1,671-1,658}{120-60}\right) \cdot(59-60)$

$=1,658+\left(\frac{0,013}{60}\right)$

$$
=1,658+\frac{-0,013}{60}
$$

$$
=1,658+(-0,0002166)
$$

$=1,6577$

Maka dari perhitungan diatas diketahui bahwa nilai t-tabel $(0,05 ; 61)$ adalah 1,6577

Untuk cari t-hitung dapat menggunakan rumus sebagai berikut :

$$
\begin{aligned}
& t=\frac{r \sqrt{ } n-2}{\sqrt{ } 1-r^{2}} \\
& t \text {-tabel }=t(a) \cdot(n-2) \\
& t=\frac{0,737 \sqrt{ } 61-2}{\sqrt{ } 1-(0,737)^{2}} \\
& t \text {-tabel }=t(5 \%) \cdot(61-2) \\
& t=\frac{0,737 \sqrt{59}}{\sqrt{ } 0,456831} \\
& t-t a b e l=t(0,05) \cdot(61) \\
& t=\frac{5,661003865}{0,675892743} \\
& t-t a b e l=1,6577 \\
& t=8,3756
\end{aligned}
$$

Pengambilan keputusan menggunakan ttabel dengan kriteria sebagai berikut :

Jika t-hitung > t-tabel maka Ho ditolak; Ha diterima (signifikan)

Jika t-hitung $<$ t-tabel maka Ho diterima ; Ha ditolak (tidak signifikan)

Sehingga dari hasil pengujian diatas maka diperoleh t-hitung > t-tabel yaitu 8,3756> 1,6577 yang artinya Ho ditolak dan Ha diterima. Maka dapat disimpulkan bahwa motivasi mempunyai pengaruh yang signifikan terhadap produktifitas kerja karyawan.

\section{Uji Hipotesis}

Untuk mengetahui apakah hubungan motivasi memiliki keberartian dalam mempengaruhi produktivitas kerja, untuk mengetahui itu perlu dilakukan uji hipotesis dengan menggunakan uji t sebagai berikut:

Hipotesis : Ho : koefisien korelasi tidak signifikan 
Ha : koefisien korelasi signifikan

Ketenuan : Jika t-hitung $<$ t-tabel maka Ho diterima Ha ditolak

Jika t-hitung $>$ t-tabel maka Ho ditolak Ha diterima

$$
\begin{aligned}
& \mathrm{t}=\frac{r \sqrt{n-2}}{\sqrt{1-r}} \\
& \mathrm{t}=\frac{0,737 \sqrt{61-2}}{\sqrt{1-0,737}} \\
& \mathrm{t}=11,0386
\end{aligned}
$$

Berdasarkan hasil pengujian diatas maka didapatkan t-hitung > t-tabel yaitu 11,0386 > 1,6577 yang berarti Ho ditolak Ha diterima, yang artinya motivasi mempunyai hubungan yang signifikan terhadap produktivitas kerja pada PT. Usaha Teknik Indonesia. Jadi hipotesa yang diajukan oleh peneliti pada bab 1 diterima.

\section{KESIMPULAN dan SARAN}

\section{Kesimpulan}

Berdasarkan pembahasan dan hasil penelitian yang telah dilakukan oleh penulis dalam penelitian mengenai pengaruh Motivasi Terhadap Produktivitas Kerja Karyawan Pada PT Usaha Teknik Indonesia, maka dapat disimpulkan sebagai berikut :

1. Tingkat Motivasi pada PT Usaha Teknik Indonesia cukup Baik berdasarkan jawaban responden pada diskripsi pernyataan variabel motivasi yang jumlah keseluruhan pernyataan sebanyak 610 yang menjawab sangat setuju (SS) sebanyak 232 atau 38,04\%, Setuju (S) sebanyak 209 atau 34,26\% dan menjawab Ragu-ragu (RG) sebanyak 169 atau $27,70 \%$.

2. Produktivitas Kerja Karyawan Pada PT Usaha Teknik Indonesia cukup baik berdasarkan jawaban responden yang menjawab Sangat Setuju (SS) sebanyak 262 atau 42,95\%, Setuju (S) Sebanyak 176 atau 28,85\%, Ragu-ragu (RG) sebanyak 172 atau 28,20\%,dan tidak setuju (TS) sebanyak $0 \%$, ini menunjukkan produktivitas kerja karyawan cukup baik.

3. Pengaruh motivasi terhadap produktivitas kerja karyawan cukup signifikan. Dari hasil analisis koefisien korelasi (r) diketahui adanya hubungan yang sangat kuat antara motivasi dengan produktivitas kerja karyawan yaitu rxy $=0,737$ dan hasil perhitungan koefisien determinasi diperoleh sebesar $\mathrm{KD}=54,31$ atau $55 \%$ hal ini menunjukkan besarnya kontribusi motivasi terhadap produktivitas kerja karyawan sebesar 55\%, sedangkan $45 \%$ dipengaruhi oleh faktorfaktor lain dan uji hipotesisnya t-hitung $>$ -ttabel yaitu sebesar 11,0386 > 1,6577 yang berarti Ho ditolak dan Ha diterima.

\section{Saran}

Dari hasil kesimpulan diatas dimana Pengaruh Motivasi Terhadap Produktivitas Kerja Karyawan cukup signifikan maka penulis ingin memberikan saran sebagai berikut :

1. Hendaknya pimpinan lebih sering memberikan perhatian terhadap karyawannya agar dapat termotivasi dalam bekerja.

2. Hendaknya perusahaan berusaha membentuk sikap karyawan agar selalu bersikap dan berperilaku baik serta ramah terhadap sesama karyawan agar dapat terwujud kondisi kerja yang harmonis.

3. Demi terwujudnya tujuan yang saling menguntungkan kedua belah pihak diharapkan adanya jalinan komunikasi yang baik, teratur dan berkesinambungan antara pihak perusahaan dan karyawan.

\section{DAFTAR PUSTAKA}

Almasdi dan Jusuf Suit "Aspek Sikap Mental Dalam Manajemen Sumber Daya Manusia" Syiar Media, 2012

Arikunto, Suharsim , "Prosedur Penelitian",PT. Rineka Cipta,Jakarta, 1998

As'ad, Muhamad "Psikologi Industry Seni Ilmu SDM" Yogyakarta, 2005 
Bascal, Robert "How To Performance" terjemahan Juli, 2005

Fazwi, Ahmad "Manajemen Sumber Daya Manusia untuk perusahaan" Grafindo, 2005

Ghouzali, Saydam,BC "Manajemen Sumber Daya Manusia" Cetakan kedua,PT BPFE,Yogyakarta, 2004

Hadari, Nawawi. "Manajemen Sumber Daya Manusia". Ghalih Indonesia, Jakarta, 2008

Handoko, T.H ani, "Manajemen Personalia dan Sumber Daya Manusia" Edisi kedua,PT. BPFE,Yogyakarta, 2012

Hasibuan, S.P. Malayu "Manajemen Sumber Daya Manusia"Edisi Revisi, Bumi Aksara Jakarta, 2002

Istinjo, EOI MM, Mcom "Riset Sumber Daya Manusia” PT.Gramedia Pustaka Utama, Jakarta, 2002

Mangkunegara A.A Anwar Prabu "Manajemen Sumber Daya Manusia Perusahaan" Cetakan Pertama, Remaja Rosda Karya, Bandung, 2005

Notoadmojo, Soekidjo "Pengembangan Manajemen Sumber Daya Manusia" Edisi keempat, PT.Rineka Cipta,Jakarta, 2009

Payman J Simanjuntak “Manajemen" Grafindo, 2005

Randall S. Schuler, Susan E. Jackson "Manajemen Sumber Daya Manusia" Jilid 2 edisi ke-6 Erlangga, 1996

Samsudin, Sadili, "Manajemen Sumber Daya Manusia" CV. Pustaka Setia, Bandung, 2006

Sadarmayanti, "Sumber Daya Manusia Dan Produktivitas Kerja". Mandar Maju, Bandung, 2001

Siagian, P. Sondang, "Manajemen Sumber Daya Manusia”, Bumi Aksara, Jakarta, 2004

Sinungan, Muchdarsyah, "Produktivitas Apa Dan Bagaimana", Bumi Aksara, Jakarta, 2003

Sugiyono, "Metode Penelitian Kuantitatif dan Kualitatif R\&D”, Alfabeta, Bandung, 2011
Umar, Husein, "Riset Sumber Daya Manusia dalam organisasi", PT.Gramedia Pustaka Utama, Jaharta, 2002

Veithzel, Rival "Manajemen Sumber Daya Manusia untuk Perusahaan" Grafindo, 2005

Wibowo. Prof, Dr, SE, M.Phill "Manajemen Kinerja”, PT. Rajagrafindo Persada, Jakarta, 2007

Yuniarsih, Tjuju \& Suwanto "Manajemen Sumber Daya Manusia", Alfabeta,Bandung, 2008 